\title{
Measurement of macrophage cellular procoagulant activity
}

Citation for published version (APA):

Muller, A. D., van Dam-Mieras, M. C. E., \& Hemker, H. C. (1985). Measurement of macrophage cellular procoagulant activity. Haemostasis, 15(2), 108-113. https://doi.org/10.1159/000215130

Document status and date:

Published: 01/01/1985

DOI:

10.1159/000215130

Document Version:

Other version

\section{Please check the document version of this publication:}

- A submitted manuscript is the version of the article upon submission and before peer-review. There can be important differences between the submitted version and the official published version of record.

People interested in the research are advised to contact the author for the final version of the publication, or visit the DOI to the publisher's website.

- The final author version and the galley proof are versions of the publication after peer review.

- The final published version features the final layout of the paper including the volume, issue and page numbers.

Link to publication

\footnotetext{
General rights rights.

- You may freely distribute the URL identifying the publication in the public portal. please follow below link for the End User Agreement:

www.umlib.nl/taverne-license

Take down policy

If you believe that this document breaches copyright please contact us at:

repository@maastrichtuniversity.nl

providing details and we will investigate your claim.
}

Copyright and moral rights for the publications made accessible in the public portal are retained by the authors and/or other copyright owners and it is a condition of accessing publications that users recognise and abide by the legal requirements associated with these

- Users may download and print one copy of any publication from the public portal for the purpose of private study or research.

- You may not further distribute the material or use it for any profit-making activity or commercial gain

If the publication is distributed under the terms of Article $25 \mathrm{fa}$ of the Dutch Copyright Act, indicated by the "Taverne" license above, 


\title{
Measurement of Macrophage Cellular Procoagulant Activity
}

\author{
A.D. Muller, M.C.E. van Dam-Mieras, H.C. Hemker \\ University of Limburg, Biomedical Center, Department of Biochemistry, Maastricht, The Netherlands
}

Key Words. Cellular procoagulant activity · Thromboplastin · Vitamin K dependent clotting factors $\cdot$ Endotoxin stimulation

\begin{abstract}
We developed a simple technique for the measurement of the procoagulant activity exposed on the surface of macrophages. The cells are isolated, adhered to plastic surfaces, and assayed in the same device. This approach allows us to study the microcoagulation on the surface of intact macrophages by sensitive and specific clotting tests.
\end{abstract}

\section{Introduction}

Fibrin deposition has been shown to occur in a variety of pathological situations of proven or suspected immunopathological origin. Monocytes and macrophages have been described to express procoagulant activity on their surface upon stimulation; the other leucocytes do not display this behaviour [1-10]. Combining these two facts it is evident that a study of the procoagulant behaviour of monocytes and macrophages under different experimental conditions probably will give us a deeper insight into the mechanism of clotting activation under pathological conditions.

Different types of macrophage procoagulant activity have been described, e.g., thromboplastin-like activity $[1-3,5,11]$, fac- tor $\mathrm{X}$ activating activity [6-9], and thrombinactivating activity $[2,3,10]$. However, in most studies the macrophage procoagulant activity was determined after transfer of the cells from the culture dish to the device in which the test was carried out and/or after lysis of the cells. These types of manipulation of the cells will certainly introduce variables not necessarily present in vivo, and this makes the interpretation of the physiological meaning of the results more difficult. We, therefore, designed a procedure in which the in vitro handling of the cells was reduced to a minimum. After the usual isolation procedure the cells are seeded in small plastic tubes instead of in culture Petri plates. The measurement of the cellular procoagulant activity can then be carried out in the same culture tube after discarding the medium. This ap- 
proach enables us to determine the cellular procoagulant activity of the adhering cells without detaching and transferring them.

\section{Materials and Methods}

Only analytical-grade chemicals were used; all solutions were prepared in distilled water.

\section{Animals}

Brown Norway rats (14-weeks-old females) bred under pathogen-free conditions were used. One group of animals was anticoagulated by the addition of warfarin to the drinking water $(2 \mathrm{mg} / \mathrm{ml})$ during 3 weeks. The degree of anticoagulation of the rats was determined in a species-specific test system [12].

\section{Isolation and Culture of Cells}

Rat spleen macrophages were obtained according to the method of Bøyum [13]. Rat peritoneal macrophages were obtained by peritoneal washing with heparinized Hanks' solution (free of $\mathrm{Ca}^{2+}$ and $\mathrm{Mg}^{2+}$ ). Rat alveolar macrophages were obtained by pulmonary washing with heparinized Hanks' solution (free of $\mathrm{Ca}^{2+}$ and $\mathrm{Mg}^{2+}$ ). Macrophage preparations were purified using Percoll gradient centrifugation (30-80\% after red cell lysis with $\left.\mathrm{NH}_{4} \mathrm{Cl}: 0.16 \mathrm{~mol} / \mathrm{l}\right)$.

Cells were routinely cultured in RPMI supplemented with $10 \%$ fetal calf serum and seeded in plastic culture tubes $(50 \mathrm{~mm}$ high; diameter $10 \mathrm{~mm} ; 2 \times$ $10^{5}$ cells seeded/tube; volume $0.2 \mathrm{ml}$ ). After $2 \mathrm{~h}$ culture in an atmosphere of $5 \% \mathrm{CO}_{2}$ in air the supernatant containing the non-adherent cells was discarded and replaced by serum-free medium. Incubations were carried out at $37^{\circ} \mathrm{C}$ in an atmosphere of $5 \% \mathrm{CO}_{2}$ in air. Analysis of the cell composition was performed on cytocentrifuge preparations stained with Giemsa or non-specific esterase [14]. At least 200 cells were counted per slide. The purity of the macrophage preparations was at least $96 \%$. The viability of the cells as assessed by trypan blue exclusion was at least $97 \%$.

\section{Culture medium}

This consisted of RPMI 1640 medium (Flow Laboratories), penicillin (Gibco; final concentration 100 $\mathrm{IU} / \mathrm{ml}$ ), transferrin (Behringwerke; final concentration $10 \mu \mathrm{g} / \mathrm{ml}$ ), and albumin (Behringwerke; final concentration $0.4 \mathrm{mg} / \mathrm{ml}$ ). In several experiments this culture medium was supplemented with additional compounds; the exact composition of the culture medium will be specified in the description of the individual experiments. Culture medium and reagents were free from endotoxin contamination as determined by a chromogenic substrate endotoxin assay (Kabi Vitrum Diagnostica) [15].

\section{Measurement of Procoagulant Activity}

Procoagulant activity was always determined in the species-specific test system that has been described by van Dam-Mieras et al. [12]. Procoagulant activity exposed on the cellular surface was determined in the plastic culture tube after removal of the culture medium. The determination was carried out in the following way: pipette into the plastic tube containing the adherent cells $0.2 \mathrm{ml}$ standard plasma or factor-deficient reagent diluted 1:1 with Michaelis buffer, incubate at $37^{\circ} \mathrm{C}$ during $15 \mathrm{~min}$ and add $0.1 \mathrm{ml} \mathrm{CaCl}_{2}(33$ $\mathrm{mmol} / \mathrm{l}$ ), and register the clotting time.

The plasma procoagulant activity or procoagulant activity secreted into the culture medium was determined in the following way: $0.1 \mathrm{ml}$ sample, $0.1 \mathrm{ml}$ thromboplastin, $30 \mathrm{~s}$ incubation at $37^{\circ} \mathrm{C}$ in a glass tube, $0.1 \mathrm{ml} \mathrm{CaCl}_{2}(33 \mathrm{mmol} / \mathrm{l})$, registration of the clotting time.

For the determination of the activity of the individual clotting factors the following experimental design was used in the determination of the factors II, VII, and X: $0.1 \mathrm{ml}$ sample diluted with Michaelis buffer, $0.1 \mathrm{ml}$ factor-deficient plasma (II, VII or X), $0.1 \mathrm{ml}$ thromboplastin, $30 \mathrm{~s}$ incubation at $37^{\circ} \mathrm{C}$ in a glass tube, $0.1 \mathrm{ml} \mathrm{CaCl}_{2}(0.033 \mathrm{mmol} / \mathrm{l})$, registration of the clotting time.

The factor IX determination was carried out as follows: $0.1 \mathrm{ml}$ sample diluted with Michaelis buffer, 0.1 $\mathrm{ml}$ factor IX deficient plasma, $0.1 \mathrm{ml}$ aPTT reagent, $300 \mathrm{~s}$ incubation at $37^{\circ} \mathrm{C}$ in a glass tube, $0.1 \mathrm{ml} \mathrm{CaCl}_{2}$ $(0.033 \mathrm{mmol} / \mathrm{l})$, registration of the clotting time.

The clotting factor levels are expressed in percent of standard plasma by comparison of the clotting time observed in the experiment with those obtained with a series of dilutions of a standard plasma. All determinations were carried out in triplicate.

Rat standard plasma was obtained by pooling equal amounts of platelet-free plasma from 30 Brown Norway rats and was stored in small portions at $-20^{\circ} \mathrm{C}$ until use [16]. Rat brain thromboplastin (Brown Norway rats) was prepared as described before [16]. Rat artificial factor II reagent was prepared 
according to the method of Koller et al. [17] using oxalated rat plasma and rat serum.

Human standard plasma was obtained by pooling equal amounts of platelet-free plasma from at least 30 healthy individuals ( 15 males and 15 females, average age 30 years) and was stored in small portions at $-20^{\circ} \mathrm{C}$ prior to use [16]. Human brain thromboplastin was prepared as described before [16]. Human artificial factor II reagent was prepared according to the method of Koller et al. [17] using human oxalated plasma and human serum. For the determination of the clotting factors VII, IX, and X human congenital factor deficient reagents were used. aPTT reagent was obtained from Dade.

\section{Results and Discussion}

In order to be able to analyze the cellular procoagulant activity of monocytes and macrophages the isolation and assay procedures have to be rigorously standardized. The standardization of the assay procedure has been described before [12], and all the determinations of macrophage procoagulant activity described in this article are performed by using a species-specific test system.

Three different macrophage populations were isolated from Brown Norway rats: spleen macrophages, peritoneal macrophages, and alveolar macrophages. The cells were cultured in serum-free medium for $24 \mathrm{~h}$ in the presence of either vitamin K or warfarin, and after $24 \mathrm{~h}$ the procoagulant activity on the cellular surface and the levels of the individual clotting factors in the supernatant were determined. The results are given in table I.

From table I it can be concluded that the activity of vitamin $\mathrm{K}$ dependent clotting factors in the supernatant is completely abolished by the addition of warfarin to the culture medium. The difference between the vitamin $\mathrm{K}$ dependent factors on the one hand and factor $\mathrm{V}$ on the other strongly suggests that the coagulation factors are indeed secreted by the macrophage and that no aspecific artefact is present. The presence of warfarin in the culture medium has no influence upon the amount of factor $\mathrm{V}$ found in the supernatant. The addition of warfarin to the culture medium also has a small, but very reproducible inhibitory effect on the cellular procoagulant activity. This suggests that, in addition to thromboplastin, also some vitamin $\mathrm{K}$ dependent procoagulant activity is exposed on the surface.

It can also be seen from table I that macrophages isolated from rat spleen show no, or only minimal, cellular procoagulant activity, while macrophages isolated from peritoneal fluid and rat alveolar macrophages exhibit a pronounced procoagulant activity. This difference in the cellular procoagulant activity of macrophages isolated from different anatomical sites has also been reported in the literature $[8,18]$ and is probably related to functional differentiation of macrophages and/or to the state of activation of the macrophage in the source organ.

In the experiments given in table II we were obliged to test the rat macrophages in a human test system, because no factor-deficient plasmas are available from a rat source. For reason of comparison the overall procoagulant activity is also measured in a human standard plasma. The measurement of the overall clotting activity in a rat standard plasma gives clotting times that are appreciably shorter (about $20 \mathrm{~s}$ ) than those obtained with a human standard plasma.

It can be seen from table II that the presence of endotoxin in the culture medium induces the expression of procoagulant activity on the surface of rat spleen macrophages. This procoagulant activity may be expected to be of the thromboplastin type $[1-3,5,11]$. 
Table I. Comparison of rat spleen, alveolar and peritoneal macrophages

\begin{tabular}{|c|c|c|c|c|c|c|}
\hline \multirow{2}{*}{$\begin{array}{l}\text { Addition to } \\
\text { culture medium }\end{array}$} & \multirow{2}{*}{$\begin{array}{l}\text { Cellular } \\
\text { procoagulant } \\
\text { activity }\end{array}$} & \multicolumn{5}{|c|}{ Procoagulant activity in the supernatant } \\
\hline & & $\%$ II & $\%$ VII & $\% \mathrm{IX}$ & $\% \mathrm{X}$ & $\% \mathrm{~V}$ \\
\hline \multicolumn{7}{|l|}{ No cells $(n=10)$} \\
\hline Vitamin K & $59.7 \mathrm{~s}$ & $<0.5$ & $<0.5$ & $<0.5$ & $<0.5$ & $<0.5$ \\
\hline Warfarin & $59.2 \mathrm{~s}$ & $<0.5$ & $<0.5$ & $<0.5$ & $<0.5$ & $<0.5$ \\
\hline \multicolumn{7}{|c|}{ Peritoneal macrophages $(n=5)$} \\
\hline Vitamin $\mathrm{K}$ & $40.8 \mathrm{~s}$ & 10 & 5 & 5.5 & 10 & 6 \\
\hline Warfarin & $44.9 \mathrm{~s}$ & $<0.5$ & $<0.5$ & $<0.5$ & $<0.5$ & 6 \\
\hline \multicolumn{7}{|c|}{ Spleen macrophages $(n=8)$} \\
\hline Vitamin $\mathrm{K}$ & $58.2 \mathrm{~s}$ & 12 & 5 & 6 & 7 & 1 \\
\hline Warfarin & $61.8 \mathrm{~s}$ & $<0.5$ & $<0.5$ & $<0.5$ & $<0.5$ & 1 \\
\hline \multicolumn{7}{|c|}{ Alveolar macrophages $(n=3)$} \\
\hline Vitamin $\mathrm{K}$ & $41.0 \mathrm{~s}$ & 14 & 6 & 5.5 & 7 & 2 \\
\hline Warfarin & $45.2 \mathrm{~s}$ & $<0.5$ & $<0.5$ & $<0.5$ & $<0.5$ & 2 \\
\hline
\end{tabular}

Macrophages were cultured in serum-free medium for $24 \mathrm{~h}$; final concentration of additions: vitamin $\mathrm{K}$ $0.1 \mu \mathrm{g} / \mathrm{ml}$; warfarin $12.5 \mu \mathrm{g} / \mathrm{ml}$.

Table II. Influence of endotoxin on the cellular procoagulant activity of rat spleen macrophages

\begin{tabular}{lcccc}
\hline Test plasma & 1 & $\begin{array}{l}2 \\
\text { Macrophages plus } \\
\text { endotoxin }(100 \mu \mathrm{g} / \mathrm{ml})\end{array}$ & $\begin{array}{l}\text { Rat } \\
\text { thromboplastin }\end{array}$ & $\begin{array}{l}\text { Rat } \\
\text { thromboplastin }\end{array}$ \\
\hline Human standard plasma & $148 \mathrm{~s}$ & $75 \mathrm{~s}$ & $148 \mathrm{~s}$ & $74 \mathrm{~s}$ \\
II deficient $(\mathrm{n}=1)$ & $10 \mathrm{~min}$ & $8.5 \mathrm{~min}$ & $10 \mathrm{~min}$ & $10 \mathrm{~min}$ \\
V deficient $(\mathrm{n}=2)$ & $48 \mathrm{~s}$ & $40 \mathrm{~s}$ & $160 \mathrm{~s}$ & $82 \mathrm{~s}$ \\
VII deficient $(\mathrm{n}=2)$ & $240 \mathrm{~s}$ & $232 \mathrm{~s}$ & $235 \mathrm{~s}$ & $159 \mathrm{~s}$ \\
IX deficient $(\mathrm{n}=4)$ & $175 \mathrm{~s}$ & $130 \mathrm{~s}$ & $192 \mathrm{~s}$ & $112 \mathrm{~s}$ \\
X deficient $(\mathrm{n}=3)$ & $245 \mathrm{~s}$ & $245 \mathrm{~s}$ & $265 \mathrm{~s}$ & $183 \mathrm{~s}$ \\
VIII deficient $(\mathrm{n}=6)$ & $190 \mathrm{~s}$ & $221 \mathrm{~s}$ & $150 \mathrm{~s}$ & $76 \mathrm{~s}$ \\
XI deficient $(\mathrm{n}=2)$ & $46 \mathrm{~s}$ & $46 \mathrm{~s}$ & $149 \mathrm{~s}$ & $75 \mathrm{~s}$ \\
XII deficient $(\mathrm{n}=2)$ & $170 \mathrm{~s}$ & $145 \mathrm{~s}$ & $200 \mathrm{~s}$ & $110 \mathrm{~s}$ \\
\hline
\end{tabular}

After purification and adhesion, the cells are incubated with culture medium (1) or with culture medium supplemented with endotoxin (2) for $30 \mathrm{~min}$. After the incubation the supernatant is discarded and the cellular procoagulant activity is determined. The thromboplastin solution was diluted so as to give clotting times corresponding to those of the non-stimulated and the stimulated macrophages. 
Endotoxin stimulation would than be equivalent to an augmentation of the thromboplastin concentration. In order to further characterize the exposed cellular procoagulant activity we compared it to thromboplastin from the same species. In the last two columns of table II the clotting times observed when starting the clotting process by the addition of rat thromboplastin are shown. The thromboplastin dilutions are chosen so as to give the same clotting times as the unstimulated and the stimulated macrophages, respectively. If the macrophage procoagulant activity were only of the thromboplastin type, one would expect that the effect of 'thromboplastin dilution' on the cellular surface (column 2-column 1) would lead to the same result as the dilution of the rat thromboplastin suspension (column 4 - column 3). Table II shows this is not the case. We have no straightforward explanation for the observed data, but one could tentatively explain the results by the adsorption of secreted clotting factors $[4,5,12]$ on the cellular surface. Addition of endotoxin to the culture medium would then result in tissue factor exposure followed by the activation of the adsorbed clotting factors. The one-stage clotting factor determination measures the total amount of clotting factors and does not discriminate between activated and non-activated clotting factors because the factors are fully activated during the test. Therefore, the differences between columns 2 and 1 are much smaller than those between the columns 4 and 3 (table II). Also the observation that systemic anticoagulation of rats by warfarin leads to a reduction of the procoagulant activity on the surface of peritoneal macrophages [19], points in this direction. Finally, one might wonder if the very reproducible finding that endotoxin stimulation of the macrophage population results in an increased clotting time when tested in a factor VIII deficient reagent might point to the secretion and activation of the vitamin $\mathrm{K}$ dependent protein $\mathrm{C}$ on the cellular surface [20]. Experiments to further characterize the cellular procoagulant activity of monocytes and macrophages are presently being carried out.

The presence of fibrin deposits in a variety of pathological situations necessitates a careful analysis of the macrophage cellular procoagulant activity and its generation during stimulation of the cells. The early observation of Béguin et al. [1] that peritoneal macrophages from sensitized animals 'shed' more thromboplastin-like activity into the supernatant during in vitro culture than peritoneal macrophages from non-sensitized animals and our observation that anticoagulation of the animal reduces the clearance velocity of intraperitoneally injected virus particles [19] both point to an active role of macrophage procoagulant activity in the immune defense reaction. The elucidation of the physiological function of macrophage procoagulant activity and insight in the processes taking place at the cellular surface might enable their therapeutic manipulation, perhaps also through anticoagulation.

\section{Acknowledgements}

We would like to thank Mr. F. Weekers and Mr. S. Vaessens for attending the rats and Mrs. M. Molenaar for secretarial assistance.

\section{References}

1 Béguin, S.; Goutner, A.; Josso, F.: Tissue factor activity of rabbit peritoneal macrophages: influence of immune stimulation. Ann. Immunol., Paris 128: 785-798 (1979). 
2 Edgington, T.S.: Recognition coupled responses of the monocyte: activation of coagulation pathways. Nouv. Revue fr. Hémat. 25: 1-6 (1983).

3 Schwarz, B.S.; Levy, G.A.; Curiss, L.K.; Fair, D.S.; Edgington,T.S.: Plasma lipoprotein induction and suppression of the generation of cellular procoagulant activity in vitro. Two procoagulant activities are produced by peripheral blood mononuclear cells. J. clin. Invest. 67: 1650-1658 (1981).

4 Østerud, B.; Lindahl, U.; Seljelid, R.: Macrophages produce blood coagulation factors. FEBS Lett. 120: 41-43 (1980).

5 Østerud, B.; Bögwald, J.; Lindahl, U.; Seljelid, R.: Production of blood coagulation factor $\mathrm{V}$ and tissue thromboplastin by macrophages in vitro. FEBS Lett. 127: 154-156 (1981).

6 Broze, G.J.: Binding of human factor VII and VII to monocytes. J. clin. Invest. 70: 526-535 (1982).

7 Fair, D.; Tsao, B.; Curtiss, L.; Edgington, T.: Monocytes can be induced by lipopolysaccharide stimulated $\mathrm{T}$ cells to express factor VII activity. Thromb. Haemostasis 50: 172 (1983).

8 Maier, R.V.; Hahnel, G.: Rabbit hepatic and alveolar macrophages produce a functionally different procoagulant activity. J. reticuloendoth. Soc. 34: 171 (1983).

9 Shands, J.W.: The endotoxin-induced procoagulant of mouse exudate macrophages - a factor-X activator. Blood 62: 333-340 (1983).

10 Schwarz, B.S.; Levy, G.A.; Fair, D.S.; Edgington, T.S.: Murine lymphoid procoagulant activity induced by bacterial lipopolysaccharide and immune complexes is a monocyte prothrombinase. J. exp. Med. 155: 1464-1479 (1982).

11 Prydz, H.; Allison, A.C.: Tissue thromboplastin activity of isolated human monocytes. Thromb. Haemostasis 39: 582-591 (1978).

12 Dam-Mieras, M.C.E. van; Muller, A.D., Deijk, W.A. van; Hemker, H.C.: Clotting factors secreted by monocytes and macrophages: analytical considerations. Thromb. Res. (in press, 1985).

13 Bøyum, A.: Isolation of lymphocytes, granulocytes and macrophages. Scand. J. Immunol. 5: suppl. 5, pp. 9-15 (1976).
14 Yam, L.T.; Li, C.Y.; Crosby, W.H.: Cytochemical identification of monocytes and granulocytes. Am. J. clin. Path. 55: 283-290 (1971).

15 Webster, C.J.: Principles of a quantitative assay for bacterial endotoxins in blood that uses limulus lysate and a chromogenic substrate. J. clin. Microbiol. 12: 644-650 (1980).

16 Dam-Mieras, M.C.E. van; Muller, A.D., Hemker, H.C.: Blood coagulation factors II, V, VII, VIII, IX, $\mathrm{X}$ and XI: determination by clotting assays; in Bergmeyer, Methods of enzymatic analysis, vol. V, pp. 352-365 (Verlag Chemie, Weinheim 1984).

17 Koller, F.; Loeliger, E.A.; Duckert, F.: Experiments or a new clotting factor (factor VII). Acta haemat. 6: 1-19 (1951).

18 Rothberger, H.; Dave, F.B.; Lee, T.K.; McGee, M.P.; Kardon, B.: Procoagulant activity of lymphocyte-macrophage populations in rabbits: selective increases in marrow, blood and spleen cells during Schwarzman reactions. Blood 61: 712-717 (1983)

19 Dam-Mieras, M.C.E. van; Bruggeman, C.A.; Muller, A.D.; Grauls, G.E.L.M.: Macrophage procoagulant activity; effect on macrophage dependent resistance to cytomegalovirus infection. 3rd Int. Congr. of Inflammation, Paris 1984.

20 Esmon, C.T.: Protein-C: biochemistry, physiology and clinical implications. Blood 62: 1155-1158 (1983).

Received: October 3, 1984

Accepted in revised form by editor S. Béguin: November 9, 1984

A.D. Muller, University of Limburg,

Biomedical Center, Department of Biochemistry, PO Box 616, NL-6200 MD Maastricht (The Netherlands) 